Scuola Normale Superiore

From the SelectedWorks of Mario Pianta

2005

\title{
Innovation and Employment
}

Mario Pianta 


\section{H A P T E R 21}

\section{INNOVATION AND EMPLOYMENT}

MARIO P I N T A

\subsection{INTRODUCTION}

The relationship between innovation and employment is a complex one and has long been a topical issue in economic theory. ${ }^{1}$ Moving from the classical question "does technology create or destroy jobs?" recent research has investigated the impact of different types of innovation and the structural and institutional factors affecting the quantity of employment change. Quality aspects have received increasing attention, with questions of "what type of jobs are created or destroyed by innovation?" This line of research has asked, "how does the composition of skills change" and "how does the wage structure change," leading to a large literature on skill biased technical change and on wage polarization.

This chapter examines the enormous body of scholarly research on this topic within the advanced economies. First, the perspectives, scope, and types of innovations are considered, identifying the different employment effects they may have. Second, the effects on the quantity of employment are reviewed at the firm, industry, and macroeconomic level. Third, changes in the quality of employment are examined, considering the effects on skills and wages, and the impact of organizational innovation, again at different levels of analysis. A summary of stylized facts concludes the chapter with a discussion of future research issues. 


\subsection{Perspectives and Scope of INNOVATIONS}

The literature on innovation and employment has addressed different research questions rooted in several streams of research. Table 21.1 summarizes the main perspectives in terms of assumptions as to the economic system, methodologies, and levels of empirical analysis (for a review of theoretical approaches, see Petit 1995).

The mainstream approach looks at innovation as a change in technology across the economy, leading to economic growth and employment. The lack of an explicit conceptualization of technology, either in the decisions of private agents, or in the tools of public policy, and its exogenous nature remain, however, a limitation of Keynesian growth theories, as well as of Solow's growth model (see Ch. 18 by Verspagen in this volume). Modern theories have approached the question of the employment impact of technology from two perspectives. On the one hand, growth theories have moved from an exogenous view of technological change to efforts, in the new growth theory, to conceptualize innovation - proxied by technology, learning, and educational variables - as an engine of endogenous growth. Labor economists, on the other hand, have explained changes in employment (and wages) with reference to the demography of jobs, macroeconomic factors, wage costs, bargaining modes, and the flexibility of labor markets, moving later to consider competitiveness and technology factors (see Table 21.1).

However, the fundamentally disequilibrating nature of technological change is usually treated in a context that still assumes a general (or partial) equilibrium of markets, that is, all output finds its demand, and all workers ready to accept the current wage find employment. Technological change is often reduced to new production processes (and new production functions), with the models rarely envisaging the emergence of product innovation. When employment losses appear in such studies, they rarely lead to permanent (or structural) unemployment; rather, they lead to downward adjustments in wages so that the additional jobless are returned to work. If this state of affairs cannot be found in the real world, then the responsibility is attached to the lack of flexibility of labor markets, with excessive union power or institutional rigidities, such as the minimum wage.

A more convincing approach to the study of innovation and its consequences is one that addresses from the start the disequilibrium nature of economic change. This view has been developed by neo-Schumpeterian perspectives, by Kaldorian, Structural, and Evolutionary approaches (see Table 21.1).

Neo-Schumpeterians have argued that advanced economies are witnessing the emergence of a new techno-economic paradigm based on Information and Communication Technologies (ICTs) (see Ch. 1 by Fagerberg in this volume). Such powerful technological changes do create and destroy a large amount of jobs. The 


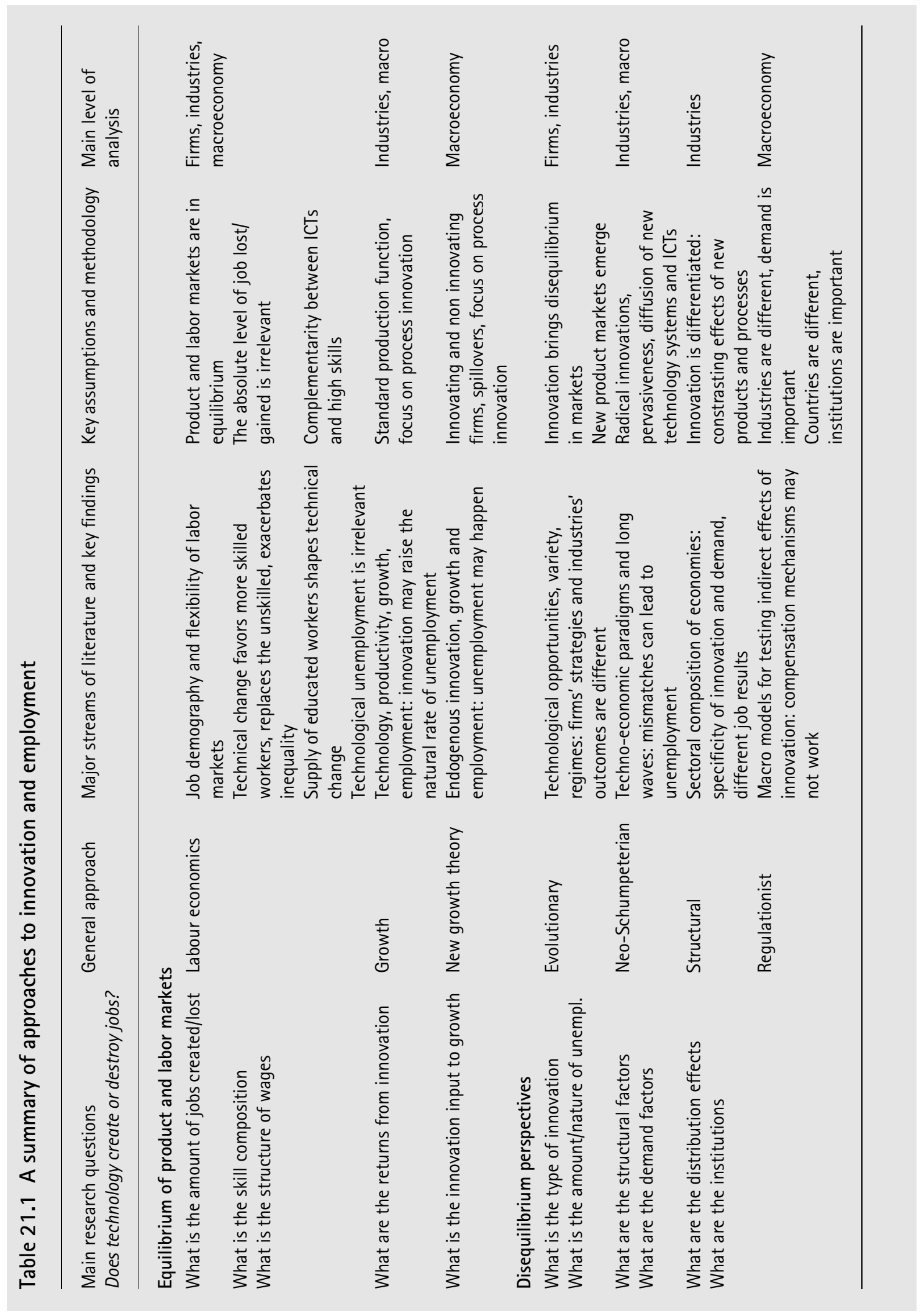


question as to where and to what extent jobs are created or destroyed depends upon the highly dynamic process that shapes the content of specific technological innovations and the speed of their adoption, with an often blurry distinction between the two (see below). Moreover, jobs lost and new jobs offered may take place in different areas or require different skills, leading to mismatches. The speed of adjustment is therefore crucial and makes the difference between frictional unemployment (easily absorbed by well-functioning labor markets) and technological unemployment.

Sustained and sustainable growth can be expected only once the mismatches between the new technologies and the old economic and social structures and institutions are overcome, with a two-way adjustment. Innovation has to be adapted to social needs and economic demands; economic and social structures evolve under pressure from new technologies. New technologies need to be matched by organizational changes, new institutions and rules, learning processes, the emergence of new industries and markets, and the expansion of new demand. Several studies on the emergence of technological paradigms and key technologies in the past have pointed to the long time required before the impact of these elements (positive or negative) on economic growth and employment become evident (Freeman, Clark, and Soete 1982; Freeman and Soete 1987, 1994; Freeman and Louçã 2001). While extremely powerful in its explanation of long term economic changes and historical evolution, this approach has yet to be "operationalized" with more specific questions on the type of innovation and on the interaction with economic and employment variables.

\section{Box 21.1 Technology and unemployment: a classical debate}

Since the emergence of the Industrial Revolution, the extensive substitution of labor by machinery incorporating the new technology of the time has led economists and policy makers to debate the economic and social consequences. At the end of the eighteenth century, James Steuart drew attention to the difficulty of reabsorbing the unemployment caused by sudden mechanization, in spite of the positive effects from the construction of new machines and price reductions, and already envisioned a role for the government. Adam Smith linked the invention of machines to the division of labor and emphasized its labor-saving effects. Jean-Baptiste Say had less doubts about the ability of markets to adjust, while Thomas Malthus emphasized the positive effects resulting from the strong demand dynamics experienced by England at the time. The optimism of classical economists in the early nineteenth century contrasted with the dramatic impoverishment of the English working classes-industrial workers, small artisans, and displaced peasants-who had started to organize trade unions and to launch Luddite struggles against the job losses and deskilling brought about by mechanization. David Ricardo was convinced that the economy could compensate the negative employment effects, but in a famous passage in the chapter "On machinery," added in the third edition of his Principles of Political Economy and Taxation, 
argued that "The opinion, entertained by the labouring class, that the employment of machinery is frequently detrimental to their interests, is not founded on prejudice and error, but is conformable to the correct principles of political economy" (Ricardo 1951:392).

The most articulate criticism of compensation theory was developed by Karl Marx, who emphasized the losses for workers in terms of jobs, skills, wages, and control over their work resulting from the way mechanization was proceeding at the time. Arguing that unemployment grows as technical change displaces labor more rapidly that the accumulation of capital demands new workers, Marx developed important insights on the functioning of capitalism. The drive to capital accumulation leads to a constant search for new production techniques and new products (a key starting point in Joseph Schumpeter's theory of innovation). High unemployment assures lower wages and greater control over workers, but capital accumulation ultimately encounters the problems of finding adequate markets and demand, and making adequate profits (for a reconstruction of the debate see Heertje 1973; Vivarelli 1995).

\subsubsection{New Products, Processes and Organizations}

Schumpeter (1934) defined product innovation as "the introduction of a new good... or a new quality of a good," and process innovation as "the introduction of a new method of production ... or a new way of handling a commodity commercially."2 The development (or the adoption) of process innovations leads to greater efficiency of production, with savings in labor and/or capital, and with a potential for price reductions. The usual outcome is higher productivity and loss of employment; to the extent that process innovations increase product quality or reduce prices, a rise in demand (when elasticity is high) may result in more jobs.

New products (or services) can be radical innovations (new to the world), incremental improvements on previous innovations, or imitation of goods already produced in other countries or firms. Generally, product innovations increase the quality and variety of goods and may open up new markets, leading (when elasticity is high) to greater production and employment. But new products can simply replace old ones, with limited economic effects, or be designed in order to reduce costs, with an impact similar to process innovations (Pianta 2001).

New goods enter the economy as consumption goods, intermediate goods, or investment goods, following the demands of consumers, firms, and investors. Innovative investment goods have a dual nature: they start as new products in the industries producing them, but become process innovations in the industries acquiring them. Their employment consequences are likely to be positive in the machinery producing sectors, and negative (when demand offsets are insufficient, as noted above) in the industries making new investments (Edquist, Hommen, and McKelvey 2001). 
The distinction between process and product innovations should not be carried too far. Most innovative firms introduce both at the same time, but in most firms and industries (see Ch. 14 by Malerba in this volume) it is possible to identify the dominant orientation of innovative efforts, associated with strategies of either price competitiveness (and mainly process innovations) or technological competitiveness (and mainly product innovations). In addition to product and process innovation, organizational innovation also can affect the quantity and quality of employment, and is usually closely linked to the introduction of new technologies (Caroli 2001). Sections 21.2 and 21.3 below will consider the impact on job creation and loss of each of these types of innovation.

\subsubsection{Innovation, Imitation, Adoption, and Use}

The employment consequences of new technologies obviously require the application of these technologies in production activities. Firms innovate when they first market a new product or introduce a new process; followers in the same industry may imitate them (perhaps with incremental improvements). Firms may adopt new processes or use new products generated in other industries, leading to the diffusion of innovations-and to their employment impact-throughout the economy (see Ch. 17 by Hall in this volume).

For empirical analyses, this distinction can be captured either by studies on the emergence of particular technologies, following their evolution through all the previous steps, or by studies on firms (or industries) based on surveys that identify product innovations novel to the market (original innovators) and those new to the firm only (imitators), and the introduction of new processes (adopters). Traditional indicators such as $\mathrm{R} \& \mathrm{D}$ and patents fail to capture a large part of the latter two modes of technological development.

$\mathrm{AU}:$

citation is missing for Box

\section{Box 21.2 Evidence on innovation and employment}

Conceptual and empirical difficulties have long led economists to adopt a rather homogeneous view of innovation, described either by $R \& D$ expenditure (one of its inputs), or proxied by patenting activity (one of its output). In the last decade, the spread of innovation surveys in Europe and of surveys on panels of firms in the US has provided important new evidence on the variety of innovative activities.

The key results for Europe in the period 1994-6 are that innovation is present in 51 per cent of manufacturing firms and in 40 per cent of services firms (see Chapters 6 and 16 by Smith and Miles in this volume). Close to 40 per cent of manufacturing firmschange their production processes, while a fifth develop minor product improvements 

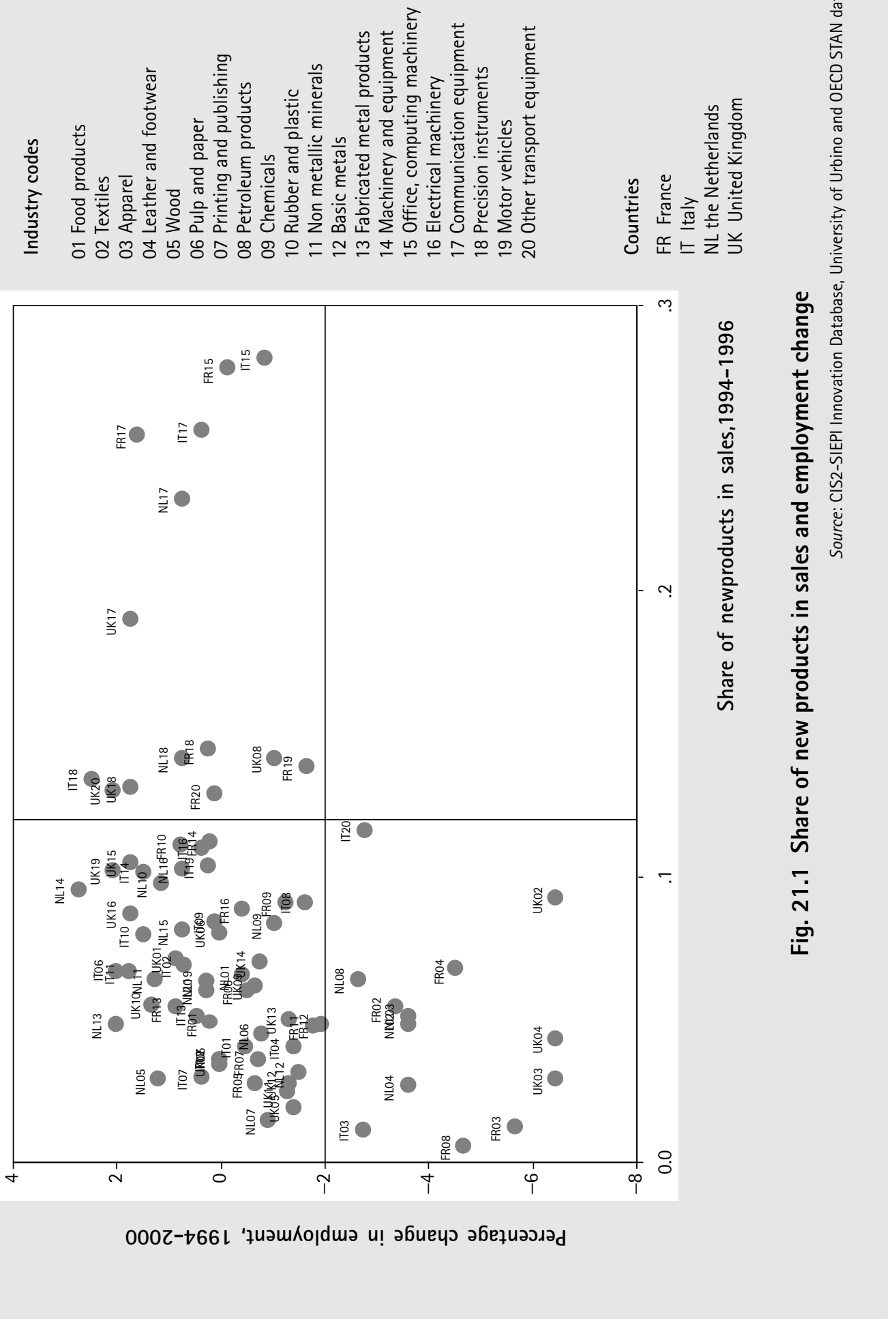
and another fifth introduce products new to their market, whose impact on sales is limited to 12 per cent. In all indicators, important differences are found across countries, associated with the nature of their industrial structure and national innovation system (European Commission-Eurostat 2001).

The latter variable offers the most accurate description of the economic relevance of innovations, and is related, in Figure 21.1, to the employment performance (average annual rate of change) of 20 manufacturing industries in four EU countries (France, Italy, the Netherlands, and the UK). Looking at industry data for the share of new products in sales (drawn from the CIS 2-SIEPI database, which provides data at the two-digit industry level for major countries), a very strong variability is evident, from more than 20 per cent in office computing and telecommunications, to close to zero in more traditional industries (again, with important cross country differences due to national specializations). Looking at overall employment change, we first see that, between 1994 and 2000, the majority of industries lost jobs. The relationship between product innovation and employment experienced in European industries looks like a positively oriented curve, but a closer look at the distribution of cases is important.

ICT industries (computing, telecommunications, precision instruments, and other transport, including aerospace) are generally in the top right quadrant, where new products in sales have a share higher than the average value for the EU and where no dramatic job losses are found. As expected, industries characterized by the new technology (and by a high concentration of product innovations) show the highest impact of new products in their turnover and better employment performances. In a few cases, however, moderate job losses are found even in this group, as strong international competition may lead to the decline of some ICT industries in some countries.

Traditional industries (textiles, wearing apparel, leather, and a few others) tend to concentrate in the bottom left quadrant, where a below average innovativeness (and a strong dominance of process innovations) is matched by dramatic job losses.

The remaining sectors, in the top left quadrant, combine a low or intermediate impact of innovation with modest job losses or substantial gains, showing again a positive association. While several factors alongside innovation affect employment change (macroecomic conditions, competitiveness, etc., see Pianta 2000), the distribution of Figure 21.1 highlights, on the one hand, the generally positive link we expect between product innovation and jobs; on the other hand, it shows the presence of winners and losers in all industries, reflecting the importance of national specializations, of economic structures, and of the intensity of international competition in open economies.

\subsection{The EFFECTS ON The QuANTity OF EMPLOYMENT}

The relationship between innovation and jobs is investigated in this section, which looks at the impact on the quantity of employment, defined in terms of the number of existing jobs, or, more accurately, in terms of the total hours of work. This link can 
be examined at different levels of analysis: firms, industries, and the aggregate economy. Table 21.2 summarizes the most relevant empirical evidence emerging from the literature.

\subsubsection{Direct Effects at the Firm Level}

Firms are where innovations are introduced and where they show their immediate direct effects on employment. A growing literature has explored the issue with a variety of models, national studies, and panels of firms (for reviews, see Petit 1995; Chennells and Van Reenen 1999; Spiezia and Vivarelli 2002). Empirical work in this field has generally used annual surveys of firms in panel data; however, panels are usually not representative of the whole manufacturing industry, and in most cases leave out services altogether; and therefore it is difficult to generalize their conclusions.

The evidence on the overall employment impact of innovation at the level of firms tends to be positive: firms that innovate in products, and also in processes, grow faster and are more likely to expand their employment than non-innovative ones, regardless of industry, size, or other characteristics. ${ }^{3}$ The variety of innovative strategies, job creation, and destruction patterns have been highlighted in such studies, together with the firms' characteristics (structural factors, flexibility, competences, etc.) that tend to be associated with better performances.

A reverse relationship can also be considered. In the long-run development of firms, phases of rapid growth of employment may be seen as determinants of innovations as firms innovate in order to cope with the rigidity of production processes and increasing wages, while trying to capture, through greater productivity and quality, the opportunities of expanding markets. ${ }^{4}$

Some studies also suggest that the positive employment effects of technological innovation are linked to organizational changes. A study on a large and representative sample of French firms found that firms that adopted advanced manufacturing systems in the period 1988-93 and introduced in parallel organizational change had greater employment growth than others, regardless of size or sector, and that this positive effect was greater than in firms that introduced organizational innovation only (Greenan 2003; see Section 21.3 below).

However, firm-level studies on the innovation-employment link are unable to point out whether the output and job gains of innovating firms are achieved at the expense of competitors, or whether there is a net effect on aggregate industry employment. ${ }^{5}$ It is often difficult to generalize beyond the groups of firms investigated and to compare results across countries. When panels are used, a large part of 


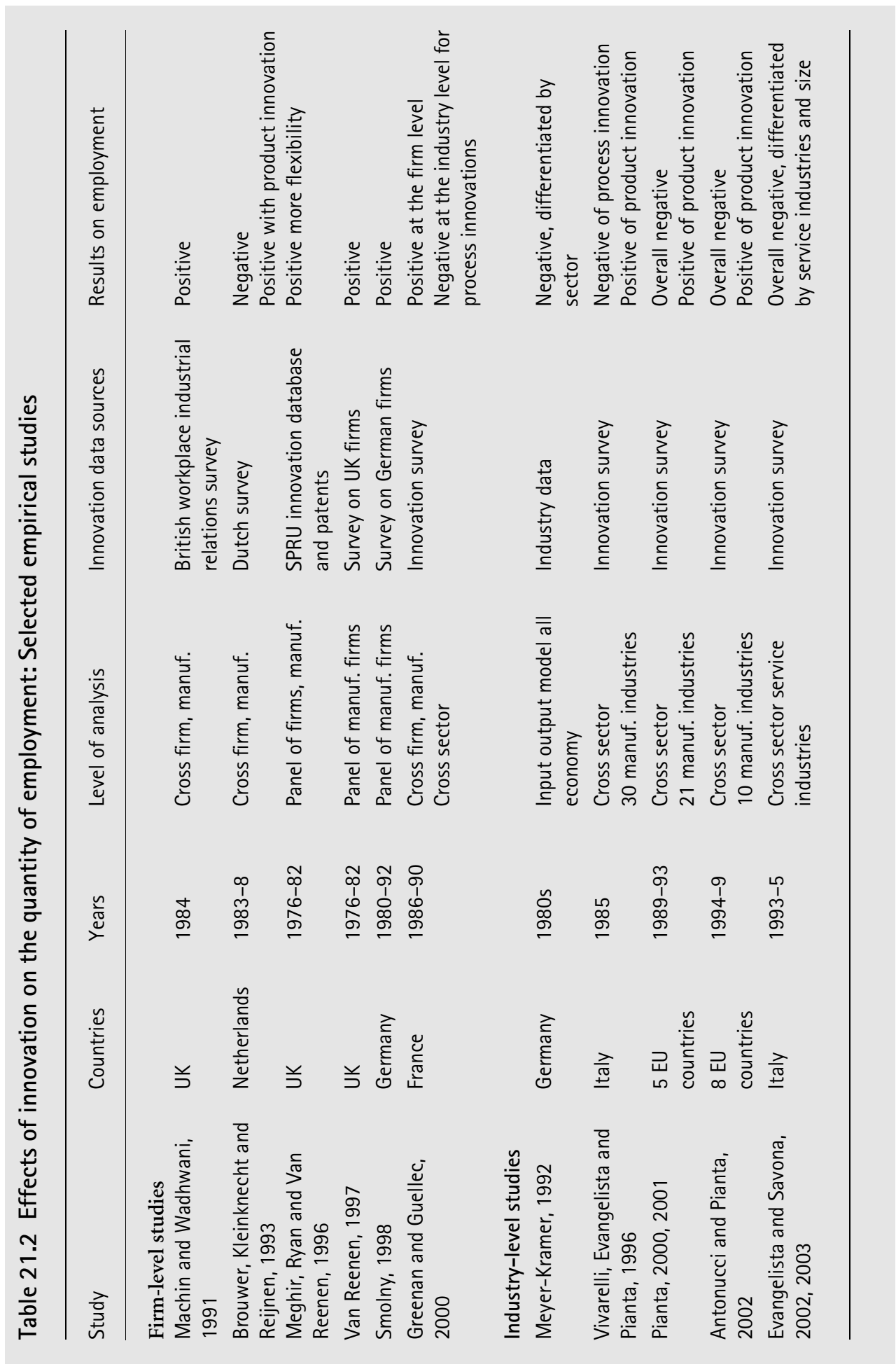




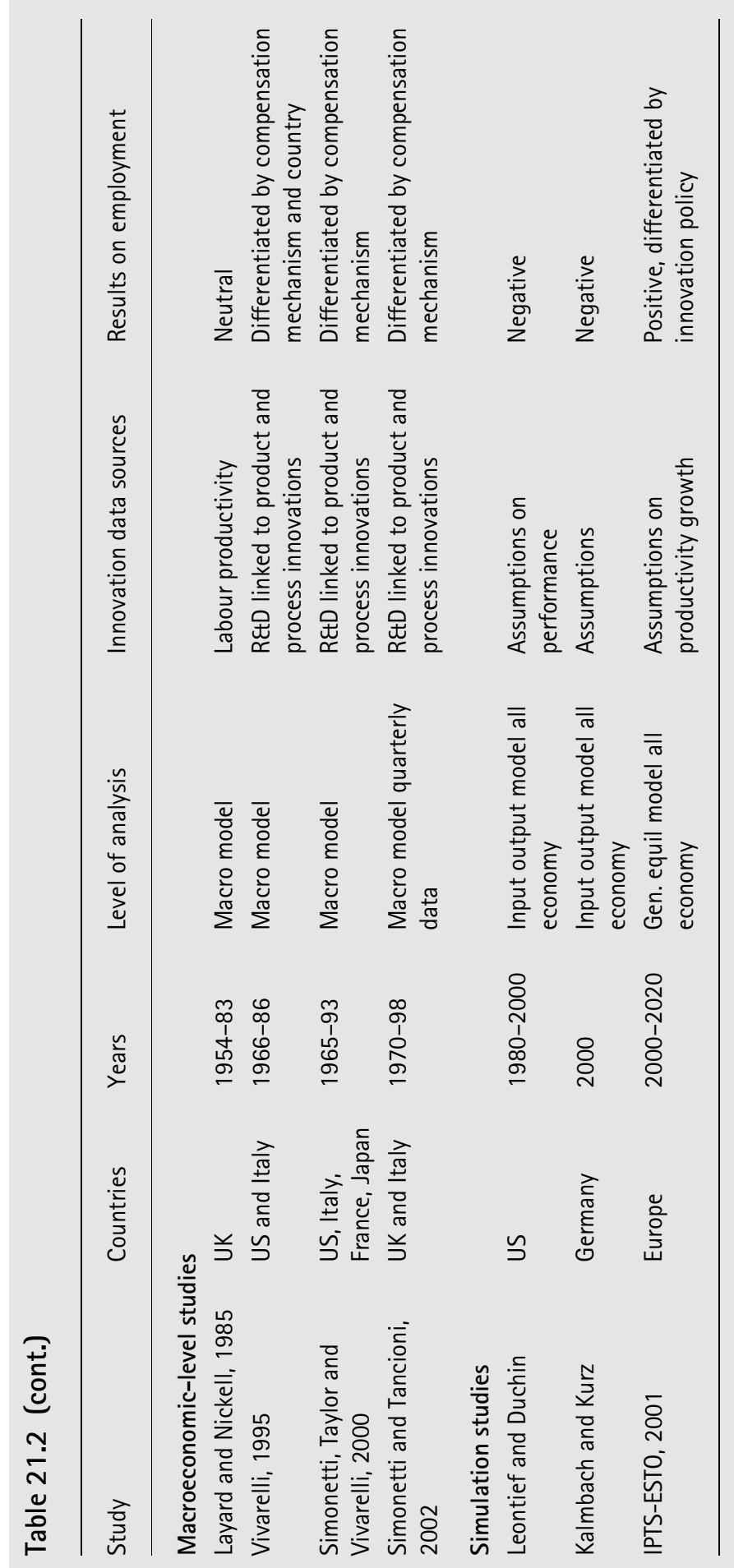


the jobs created or lost may be accounted by the entry or exit of firms left outside the panel. In order to address these issues, we need to turn to industry-level studies.

\subsubsection{The Effects at the Industry Level}

Analyses at the industry level address not only the direct employment effects of innovation within firms, but also any indirect effects that operate within the industry. These indirect effects include the competitive redistribution of output and jobs from low to high innovation-intensive firms, and the evolution of demand (and therefore output and jobs) resulting from the lower prices due to innovation, given the price elasticities of the industry's goods. The industry level may be the most satisfactory level of analysis, as it is able, on the one hand, to differentiate between the variety of technological regimes and strategies and, on the other hand, to bring in the demand dynamics of specific sectors, taking into account country differences in economic structures.

Studies on industries (see Table 21.2) show that the employment impact of innovation is positive in industries (both in manufacturing and services) characterized by high demand growth and an orientation toward product (or service) innovation, while process innovation leads to job losses. The overall effect of innovative effort depends on the countries and periods considered, but, in general, the higher the demand growth, the greater the importance of innovative industries (both in manufacturing and services) and the greater the orientation of firms within an industry toward product innovation, the more positive are the employment effects of innovation.

Demand factors are important because an industry's demand is constrained by the composition and dynamics of domestic and foreign demand. High demand growth leaves room for a variety of firm strategies and for better employment outcomes, while stagnant demand deepens the selection process among firms and emphasizes the role of technological competition (Pianta 2001). ${ }^{6}$

The empirical investigations of the employment impact of innovation at the industry level include studies using R\&D or patenting as innovation proxies, ${ }^{7}$ input-output models, ${ }^{8}$ and more recent works based on innovation surveys (unfortunately, available only for Europe). Set in the context of the European debate on "jobless growth" in the 1990s, the evidence points to an extensive process of restructuring in many manufacturing sectors where the growth of value added is not matched by increases in jobs (see Pianta, Evangelista, and Perani 1996; Fagerberg, Guerrieri, and Verspagen 1999).

Studies using innovation survey data ${ }^{9}$ show that, in Europe, employment change (in most cases a decrease) is positively affected by the dynamics of demand and by the relevance of product innovations, while a higher intensity of innovative 
expenditure per se has a negative impact on jobs, suggesting a prevailing pattern of labor-replacing technological change.

Similar findings come from a model in which employment is affected by demand dynamics, labor costs, and innovation variables on product or process innovations; in the context of the modest aggregate growth of the 1990s, European industries (in eight countries) were dominated by process innovations, with generally negative effects on jobs (Antonucci and Pianta 2002).

The findings for service industries do not differ substantially from those of manufacturing. Studies on Italy have found an overall negative effect, concentrated among the largest firms, on low-skilled workers, on capital-intensive and financerelated sectors, and where the impact of ICTs has been most widespread. Smaller firms and technology-oriented activities show, on the other hand, net employment gains (Evangelista and Savona 2002, 2003; see also Ch. 16 by Miles in this volume).

The evidence at the sectoral level, especially for European countries, suggests a less optimistic view on the employment impact of innovation. The slow aggregate growth of the 1990 s has constrained demand, limiting the potential employment benefits of technological change. While product innovation has had positive effects on output and jobs, increased international competition has pushed firms toward restructuring, and process innovations have dominated several industries in many European countries, leading to a prevalence of labor-saving effects. This contrasts with the experience of the US in the 1990s, marked by high demand and employment growth.

\subsubsection{Direct and Indirect Compensation Effects at the Macroeconomic Level}

The most complete view of the employment impact of innovation is provided by a macroeconomic perspective that can integrate all the indirect effects through which technological change affects employment. This is the approach typical of the debate on "compensation mechanisms" since the times of Ricardo and Marx, pitting those who argue that the economic system has built-in mechanisms which assure the recovery of jobs lost due to innovation, against critics who point out the limitations of their effects and the possibility of technological unemployment. Most of this debate conceptualizes technological change as the introduction of new capital goods, typical of nineteenth-century mechanization, thus conceptualizing "innovation" as "process innovation." Second, the debate typically assumes equilibrium in product markets, i.e. no demand constraint is considered, following Say's law. Recent research in this direction has relied on Kaldorian approaches, on the work by Pasinetti (1981) and Boyer (1988a and $b$ ). A detailed treatment of this issue is in 
Vivarelli (1995), who has summarized the compensation mechanisms and the way they may (or may not) operate in the economy.

The compensation mechanism via decrease in prices is one of the most important ones: new technologies may make lower prices possible, increasing international competitiveness and output, offsetting job losses due to the original innovation. This outcome, however, is contingent on the lack of demand constraints, on the decision of firms to transfer in lower prices the productivity gains due to the innovation, and on the lack of oligopolistic power in the relevant markets (Sylos Labini 1969).

The compensation mechanism via new machines may create jobs in the industries in which the new means of production are made, responding to the increased demand for equipment by users. However, at the aggregate as well as at the firm level, the rationale for mechanization is by definition saving on the overall use of labor, putting a limit on the relevance of this mechanism.

The compensation mechanism via new investment argues that the temporary extra profits available to the innovator may be turned into new investment if profit expectations are favorable (and assuming that Say's law operates); this, however, may expand production capacity and jobs, or may introduce additional labor saving effects.

The compensation mechanism via decrease in wages is typical of the neoclassical view of the labor market. As technological unemployment appears, wages should fall and firms should hire more workers. This mechanism, however, is based on strong assumptions as to the feasibility of any combination of labor and capital, competitive markets, flexibility of wages, and labor markets.

The compensation mechanism via increase in incomes operates in the opposite way, through the increased demand associated with the distribution of part of the gains from innovation through higher wages, as has happened in large, oligopolistic firms in mass production industries. However, any wage increases can hardly be large enough to sustain additional aggregate demand.

Finally new products may lead-as discussed above-to new economic activities and new markets (welfare effects) or, on the other hand, they may simply replace existing goods (substitution effect, see Katsoulacos 1986).

Aggregate empirical patterns for the US are examined in a descriptive way by Baumol and Wolff (1998). Considering five innovation indicators for the whole economy and their link to the structure and changes in unemployment in the US in the 1950-95 period, they conclude that faster innovation leads to a higher "natural rate of unemployment" and to longer spells of frictional unemployment. ${ }^{10}$ Layard and Nickell (1985), on the other hand, have argued that the working of various compensation mechanisms ruled out the possibility of technological unemployment in the UK.

Building on Boyer (1988a and $b$ ) and on the Regulationist approach, Vivarelli (1995) has developed a simultaneous equations model for testing the compensation 
mechanisms in the US and Italy. He has found that the mechanism via decrease in prices is the most effective one, and that the positive effects of new products and labor markets operate in the US (where new jobs are created), but not in Italy, where net job losses have been found. This approach has been further developed by Simonetti, Taylor, and Vivarelli (2000), who have considered four countries, and by Simonetti and Tancioni (2002), who have developed a model for an open economy in the case of the UK and Italy. All have found a differentiated impact of compensation mechanisms in different national economies.

While this approach is the most comprehensive and satisfactory for explaining the overall impact of technological change on employment, the complexity of the construction of the model, the problems in specifying all relevant relationships, and the lack of adequate data limit the feasibility of this approach. The overall findings of these studies point to a differentiated impact of innovation depending on countries' macroeconomic conditions and institutional factors. The employment impacts of innovation generally are more positive in economies in which newproduct generation and investment in new economic activities are higher, and in which the demand-increasing effects of price reductions are greater.

\subsubsection{Simulation Studies}

The employment impact of innovation has also been studied through the use of a simulation approach. Leontief and Duchin (1986) have estimated that the diffusion of computer technology and automation in the US economy would have negative employment effects using an input-output model incorporating strong assumptions on the productivity-enhancing effects of process innovation, but no demand dynamics. ${ }^{11}$ Likewise, a study on the impact of microelectronics in forty sectors of the UK economy in the 1980s suggested that either net job gains or losses were possible, depending on the assumptions on the speed of diffusion and users' demand of microelectronics (Whitley and Wilson 1982). A different approach-a general equilibrium model with a sectoral structure, which assumes full employment-has been used for simulating the employment impact of different scenarios of technology-based productivity growth and of the composition of consumption, in a recent study by IPTS-ESTO (2001) on the European Union. The results show an overall positive impact on jobs, differentiated according to the alternative sectoral distributions of R\&D and innovation efforts; the best outcomes result from the concentration of efforts in high technology industries. While they are interesting as explorations of alternative futures, the results of such simulations are weakened by the models' inability to identify either technological unemployment (when general equilibrium is used) or most compensation effects (when input-output models are 
used), and on the arbitrariness of the assumptions on the diffusion and productivity of new technologies.

Summarizing the results of this section, both sectoral and aggregate studies generally point out the possibility of technological unemployment, which emerges when industries or countries see the prevalence of process innovations in contexts of weak demand. Firms innovating in both products and processes may be successful in expanding output and jobs regardless of the economic context, but often do so at the expense of non-innovating firms. The specificities of industries, countries, and macroeconomic conditions are crucial determinants of the results obtained in empirical studies.

All the analyses of this section refer to national economies, sometimes even assuming a closed economy. When we consider an open economy, the picture becomes more complex, as, on the one hand, innovation may lead to competitiveness and exports, weakening the demand constraint while on the other hand, domestic demand may increase imports when foreign competitors are more innovative in terms of price or quality. No empirical analysis has so far addressed the innovation-employment question in a truly global dimension. In manufacturing sectors that are highly internationalized, the introduction and diffusion of innovation leads to job creation and losses in a large number of different countries, making the distribution of the benefits and costs of technological change very complex. The case of developing countries in this context is particularly interesting, as new technologies are at the center of the structural changes and dynamic learning economies typical of catching-up countries which nevertheless face greater difficulties in capturing the employment benefits of technological change (see Karaomerlioglu and Ansal 2000 and Ch. 19 by Fagerberg and Godinho in this volume).

\subsection{The EFFECTS ON THE QUALity OF EMPLOYMENT}

Most approaches that assume equilibrium in labor markets (and therefore no technological unemployment, see Table 21.1) have disregarded the effects of innovation on the quantity of jobs, focusing instead on change in the skill mix of employment and on wage polarization. A large (mainly) US literature on skill-biased technical change (reviewed in Acemoglu 2002: 7) argues that technical change is biased towards skilled workers as it replaces unskilled labor and increases wage inequality. In fact, a strong complementarity between technology and skills has 
characterized most of the twentieth century, when innovation has probably always been skill biased, in contrast to the unskilled bias typical of the nineteenth century, when mechanization led to the deskilling of artisans (see Braverman 1974). ${ }^{12}$

This section considers the streams of research that have found evidence on the complementarity between ICTs and high skills, as well as those highlighting the deskilling process associated with the greater control over production made possible by ICTs. A related finding in much of this research emphasizes the tendency for ICT adoption to increase polarization in the wage structure as a result of changes in the skill structure of employment. Another stream of this research examines the effects of organizational innovation - alone or combined with technological innovationon skills, wages, and employment (for reviews see Chennells and Van Reenen 1999; Sanders and ter Weel 2000). Table 21.3 summarizes the most relevant literature.

\subsubsection{Skill-biased Technical Change}

Many studies - mainly on US firms and industries - argue that, in the last two decades, a long-established trend of increase in the skill-intensity of employment has been accelerated by the introduction of information technology and computers. The issue has generally been investigated using a factor substitution framework, showing that direct or indirect measures of technology are important explanatory factors for the relative increase of skilled labor (see Berman, Bound, and Griliches 1994; Autor, Katz, and Krueger 1998). One stream of work compares the effects of technology with those of increased international trade, finding that the former accounted for most of the fall in demand for less-skilled workers (see Berman, Bound, and Machin 1998). Other studies have found that new technologies are adopted more extensively in plants with more skilled workers, but do not increase the demand for skills (Doms, Dunne, and Trotske 1997. See the review in Chennells and Van Reenen, 1999).

When more refined measures of skill are used, however, the evidence on skills bias is less clear. Moving from the simple measures of blue or white collar jobs, or of years of schooling, to more refined indicators of skills, including cognitive (typical of technical staff), interactive (typical of supervisory staff), and motor competences (typical of manual workers) in US industries between 1970 and 1985, Howell and Wolff (1992) found that expenditures on computers and new investment were associated with raising demand for high cognitive skill workers, although with differences across occupations and industries.

Howell (1996) rejects the idea of a link between computerization, upskilling, and wage inequality, and finds that major shifts in skill structure occurred between 1973 and 1983, with little change taking place afterwards, when the diffusion of ICTs accelerated and computer-related investment per employee increased dramatically. ${ }^{13}$ In recent years, the employment shares of high-skilled blue collars and low 


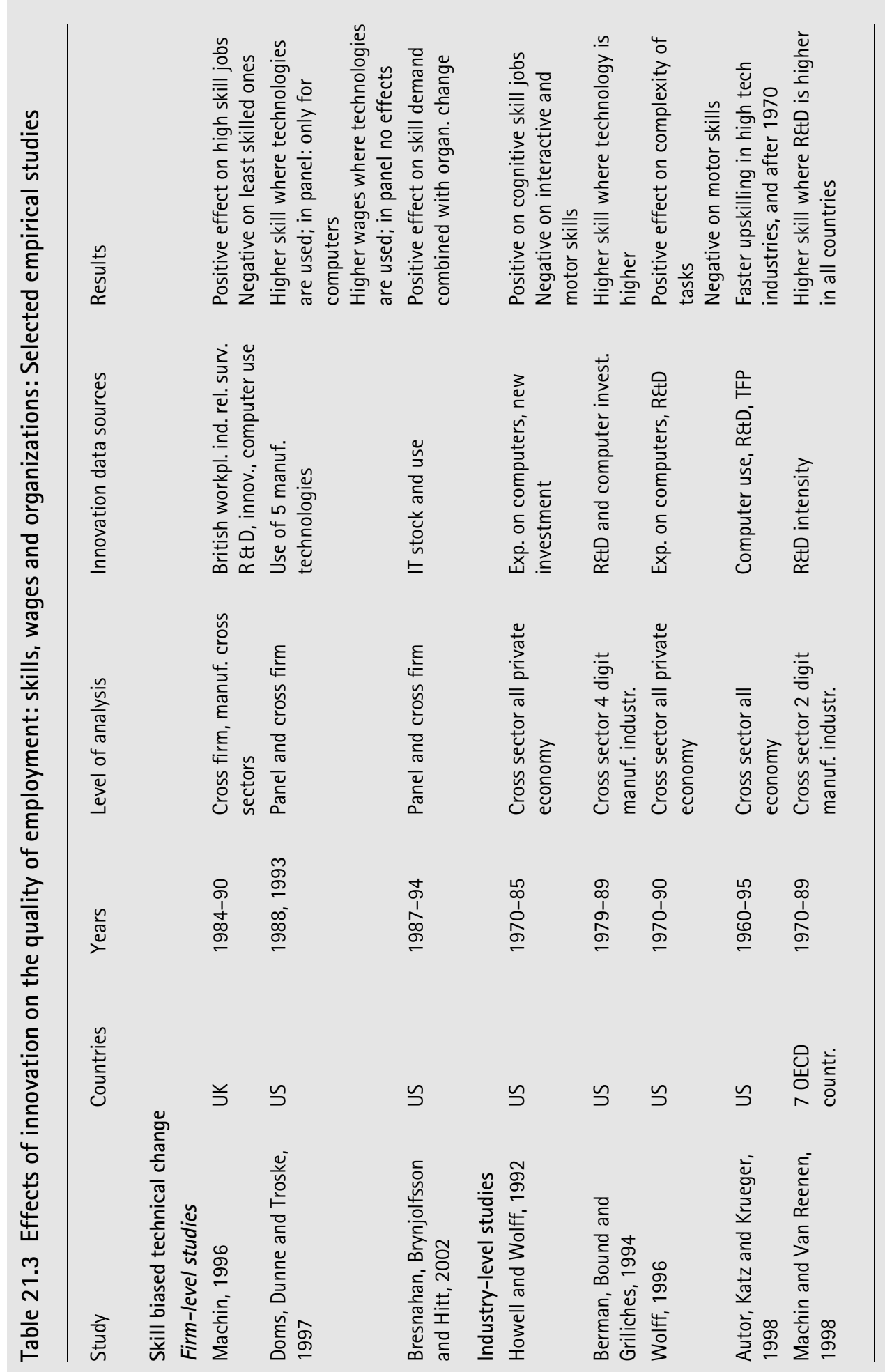




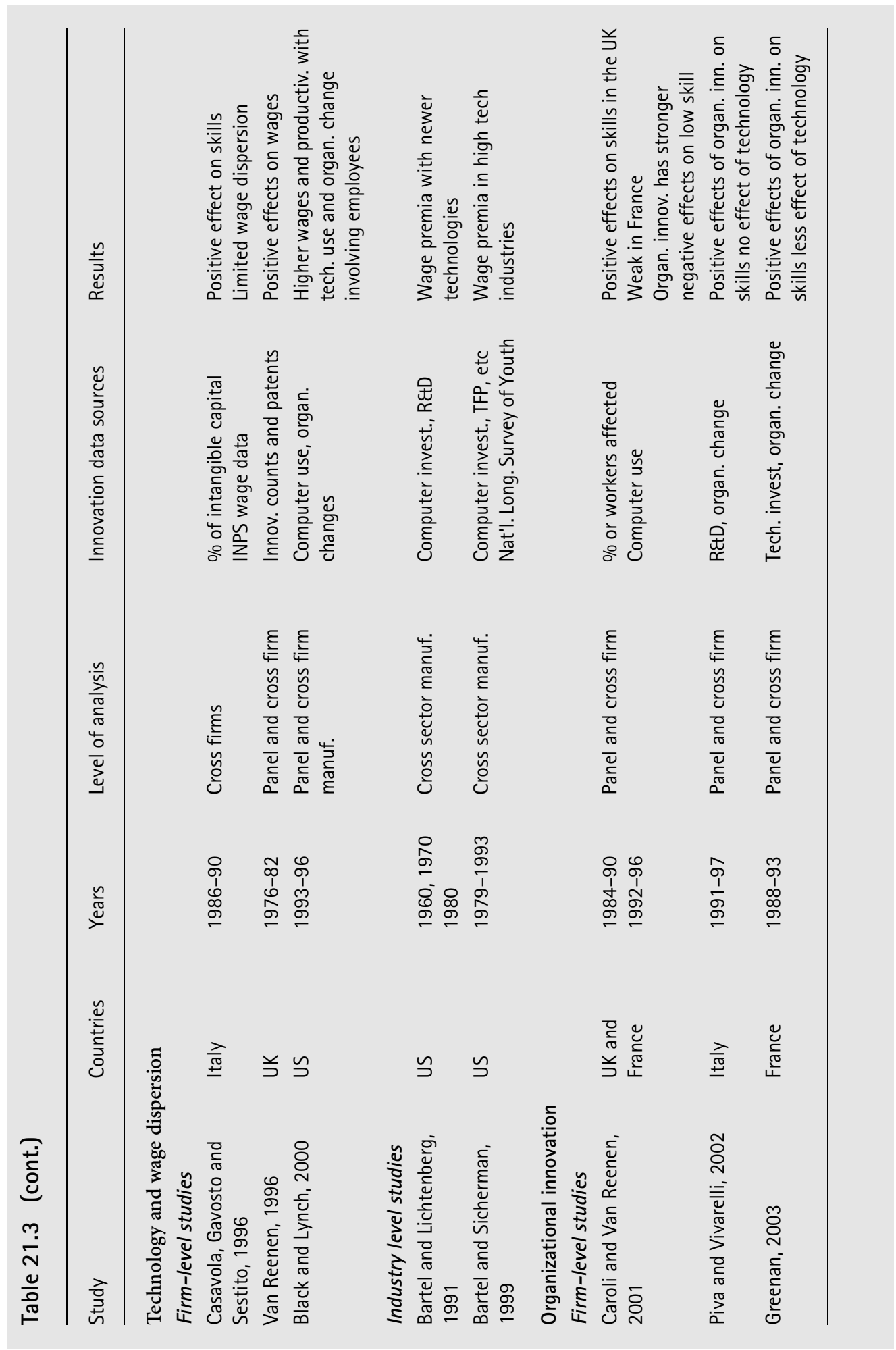


skilled white collars have declined more rapidly, and little change in the skill structure of services employment is apparent. ICT investment since the mid-1980s therefore appears to have negatively affected the low skilled white collars (mainly female) much more than the lowest blue collar skills.

\subsubsection{Wage Polarization and the Labor Market}

Although many studies do not separate the effects of technological change on skills and wages, some have investigated the evolution of wage differentials in three contexts: across industries with varying R\&D and capital intensities; among workers and firms with different levels of use of computer technology and ICTs; and among workers or social groups with different educational levels (see Sanders and ter Weel 2000; Acemoglu 2002). These studies find weak evidence of polarization, although the relationship of polarization to technological change is confounded by the tendency for computers to be used by more competent workers who already earn higher wages (Chennells and Van Reenen 1999). On the other hand, the technologywage polarization link has been questioned by studies pointing out the lack of an acceleration in these effects in recent years, and suggesting instead that sectoral shifts in employment and growing international trade have exercised more influence on the structure of wages (Addison and Teixeira 2001).

In comparing US and European results, a paradox emerges. Empirical patterns show that, in the last two decades, low skill and low wage jobs have grown more rapidly in the US than in Europe, a trend associated with the faster growth of the supply of labor, and greater polarization in the wage structure. Skill-biased technical change thus may be more a European than an American phenomenon. In this view, a stagnant labor supply and more educated workers, as well as slower aggregate growth and greater competitive pressure, have led European firms and industries to adopt technological and organizational innovations during the past two decades that have favored relatively skilled workers. The effects of this skills bias in European employment on wage polarization have been attenuated by European labor market institutions (e.g. stronger labor unions). But in the United States, faster growth of new jobs at the top and bottom end of the skill structure, combined with weaker labor unions, have produced considerable polarization in wages. ${ }^{14}$

\subsubsection{The Effects of Organizational Innovation on Employment and Skills}

In an extensive survey of organizational change in US manufacturing and service firms, Appelbaum and Batt (1994) find widespread adoption of new management 
practices in conjunction with the introduction of new technologies, but no information is provided on any change in employment levels. Both technology adoption (such as the number of non-managers using computers) and new workplace practices are closely associated with higher productivity and wages (Black and Lynch 2000). Improved performances and upskilling of the workforce are also found in US firms when ICT introduction is matched by new organizations delegating authority to workers and teams (Brynjolfsson and Hitt 2000; Bresnahan et al. 2002).

Several European studies (Caroli and Van Reenen 2001 on France and Britain; Greenan 2003 on France; Piva and Vivarelli 2002 on Italy) have shown that organizational innovation is more important than technological innovation in shaping changes in occupational structure and skills. This is generally not associated with an increase in the number of employees, with the exception of management occupations.

Organizational and technological changes in services, on the other hand, have reflected the opportunities offered by ICT to overcome time and space constraints in the provision of services, leading to major flows of job creation and destruction, and to rapidly changing skill requirements. A variety of strategies of restructuring, emergence of networks, subcontracting, and outsourcing has resulted, leading to polarization effects in skills and wages (Petit and Soete 2001b; Frey 1997).

The rather fragmented evidence so far available on organizational innovation suggests that it plays a crucial role alongside technological innovation in shaping productivity and employment outcomes. The two can have a complementary relationship (especially when a virtuous circle of growth is in place) leading to a combined effect on performance and upskilling that can be greater than their sum. On the other hand, changes in organizations or in technologies may be pursued as alternative roads in contexts of restructuring and job losses.

\subsubsection{A Broader View}

Although there is little doubt that, in the long term, technological change is associated with improvements in the skills and wages of some workers, the specific effects of innovation on employment in particular countries and periods reflect the operation of many other factors, including economic structures, the strategies of firms, the operation of labor markets rules, and institutions and national economic policies. The macroeconomic dimension is missing from much of the current literature on technological innovation and employment. Little research has addressed the broader distribution effects of technological change among profits, rents, wages, shorter work hours, and lower prices.

This literature also has restricted its focus to the demand for labor, despite abundant evidence that new technologies interact with broader social changes that 
affect the supply of labor (see Acemoglu 2002). Slower population growth, higher immigration flows, an ageing population and the forms of women's presence in the labor force all influence labor supply. In addition, the quality of labor supply-and the potential for innovation-are affected by education and training, learning processes, and the accumulation of competences by workers and firms.

\subsection{CONCLUSiOn: STYLized FaCtS AND Directions For Future Research}

This chapter has examined the relationship between innovation and employment, reviewing a large empirical literature. The complexity of the issues is such that no single approach can account for the direct and indirect consequences of technological change, or for its effects on the quantity and quality of labor employed in the economy. ${ }^{15}$ Theories and empirical research have to proceed in parallel, with a close interaction between concepts and measures, hypotheses and tests, building links to related research areas. This final section summarizes some key stylized facts emerging from the empirical evidence and highlights possible directions for future research.

\subsubsection{A Few Stylized Facts}

The never-ending race of innovation and employment. The evolution of (most) economies shows that, when growth, structural change, and demand dynamics take place together, in the long run the jobs lost to technological change are found elsewhere in the economy. If no innovation took place, economic activities facing competitive pressure would cut costs, wages, and eventually, jobs. The key question is the rate at which technological innovation and diffusion eliminate jobs, versus the pace at which new economic activities create new jobs.

Technological unemployment can happen. On the basis of the available evidence, current technological change may be a cause of unemployment. There is no automatic mechanism ensuring that national or regional economies fully compensate for innovation-related job losses. Indeed, Europe in the 1990s appears to have been a region in which technological innovation and diffusion, in combination with a long list of supporting influences, eroded employment. 
The type of innovation is important. The evidence shows that it is essential to discriminate between product innovation (novel or imitative) that has a generally positive employment impact, and process innovation (adoption and use of new technologies) usually with negative effects; these findings emerge regardless of the theoretical approach used.

Organizational innovation is closely linked to technological change. Organizational innovation is frequently an indispensable complement to the adoption of new technologies, especially ICT (see Ch. 5 by Lam in this volume). These complementary organizational changes critically affect the productivity and employment consequences of technological innovation and diffusion, especially in ICT.

One important consequence of technological innovation and adoption is change in the "skill bias" of employment. Unskilled jobs have long been declining in absolute terms (in Europe) or growing slowly (in the US), while jobs for more educated workers have been created at a faster pace in most countries and are associated with greater innovative efforts. Nevertheless, considerable uncertainty remains over the specific effects of ICT-related innovation since the 1980 os on the skill requirements of new jobs, as opposed to coincidental changes in the supply of more educated labor.

Wage polarization has been significant, although the specific effects of new technologies on this trend are difficult to identify. Since the 1980s, most countries have experienced a growing divide within wages (and more generally in incomes). This is the result of changes in economic structures, in firms' strategies, and in government policies. Technological change has almost certainly contributed to this trend, but the specific link between innovation and wage differentials is unclear. Trends in wage dispersion and inequality reflect a number of broader, coincidental trends in the evolution of labor markets, employment forms, social relations, and national policies.

Aggregate demand and macroeconomic conditions are important. Although the role of demand has generally been downplayed in the innovation literature, it may help explain the negative employment impact of innovation found in Europe in the lowgrowth decade of the 1990 (see Ch. 18 by Verspagen in this volume).

Innovation interacts with trade. In open economies, trade is an important factoralongside innovation - affecting employment and wages. The evidence available (mainly for the US) suggests that technological change has affected job losses, particularly among unskilled workers, and lower wages more substantially than has increased international trade. But the interactions between innovation and trade shape competitiveness (see Ch. 20 by Cantwell in this volume), the direction of technological change, the evolving division of labor, and the employment outcomes.

The national innovation system is a critical mediating influence in the effects of technological innovation and diffusion on employment. A country's technological opportunities and ability to develop long-term learning and innovating capabilities are rooted in the nature and characteristics of its national innovation system. Its strengths, orientation, and priorities are likely to be reflected in the employment effects of a country's innovative efforts (see Ch. 7 by Edquist in this volume). 
Labor market conditions and institutions matter. The employment outcomes of technological change depend on the operation of job markets, the operation of institutions that set wages, and the institutions influencing worker learning, flexibility, and welfare protection. Labor market institutions also influence the supply of labor, which can affect the match between labor supply and the skill and competence requirements, as well as the employment effects, of new technologies.

\subsubsection{Directions for Future Research}

The following issues emerge from this chapter as promising directions for future studies.

Both theories and empirical studies should strive to develop explanations and predictions that are consistent at the various levels of analysis of the innovationemployment relationship-firms, industries, and the aggregate economy. All too often, the findings at one level of analysis contradict the patterns at a more aggregated level. Achieving this goal requires that firm-level data be representative of whole sectors, and further requires that industry coverage includes much if not all of the economy (including services). Innovation survey data, when accessible, could make this effort possible.

Studies on firms should address the innovation-employment question in the context of the evolution of firms and market structures through the processes of diversity generation (through innovation) and selection (in the marketplace, Nelson and Winter 1982). This avenue for research recognizes that the potential for job creation depends on mechanisms of firm growth and new firm generation.

An important challenge to innovation studies is to extend empirical research to cover the service sector, rather than confining such work to manufacturing industries. From a theoretical perspective, an analysis linking structural and technological (and organizational) change is especially important for understanding the expansion of services in advanced economies. The increasing availability of industry level data also for services (such as in European innovation surveys) makes this extension possible. Since most new jobs are created in services, this extension also is essential for policy.

The need to devote greater attention to organizational innovations and to link them to technological ones has already been pointed out; this appears as a major direction for future studies.

Bringing the analysis of the innovation-employment link into the macroeconomic context of an open economy is also important, in order to highlight the interactions between technological developments on the supply side, and growth potential on the demand side, as well as the interactions between innovation and trade in shaping growth and employment outcomes. 
As international production, especially in manufacturing industries, becomes a key aspect of industrial structures, an additional level of analysis, looking at individual industries at the global level, may emerge. Data constraints are serious, but substantial evidence is now available on the international production networks of multinational corporations, and the link to employment variables across the relevant countries may become possible.

The appropriate labor market arrangements for favoring a virtuous circle between innovation and a high quantity and quality of jobs and wages, through greater learning, competence building and improved working conditions, is an additional area for future research.

Finally, as already suggested, research could address the distributional effects of innovation throughout the economy. So far, innovation has mainly benefited firms and consumers, in the form of higher profits and lower prices. When we consider also its effect on wage polarization, the result has been an increasingly uneven distribution of incomes, an issue with major policy relevance.

\section{Notes}

1. For their comments and suggestions, I wish to thank the editors, Charles Edquist, BengtÅke Lundvall, Marco Vivarelli, and several contributors to this volume.

2. The emergence of new forms of organization, the opening of new markets and of new sources of materials were other types of innovation considered by Schumpeter.

3. Generally positive effects of indicators of innovation on the number of jobs (once the characteristics of firms have been controlled for) have been found in the studies of UK firms by Van Reenen (1997), who related a large panel of manufacturing firms to the SPRU database of British innovations, and by Machin and Wadhwani (1991), using the British workplace industrial relations survey on the adoption of ICTs. In a panel of German firms, Smolny (1998) has found a positive effect of product innovation and no effect of process innovations. Dutch firms investigated by Brouwer, Kleinknecht and Reijnen (1993) showed an overall negative link between innovation and jobs, but where product innovations were dominant, better employment outcomes have been found.

4. This view is proposed by Antonelli (2001: 173) in a study on the Italian car maker Fiat over the time period 1900-1970, which shows that employment growth Granger-caused patent growth with different time lags. In turn, patent growth led to productivity growth.

5. In France, Greenan and Guellec (2000) found a positive relationship between both product and process innovation and employment at the firm level, but at the industry level, only the former played a positive role. Using data from the French household survey, Entorf, Gollac, and Kramarz (1999) found that computer use reduces the risk of unemployment in the short term, but not in the long term.

6. High demand is a necessary, but not sufficient, condition for employment growth. In order to expand jobs, demand and output have to grow faster than productivity, a condition that has been often found in the US, but not so much in Europe. 
7. Typical of the former approach is the OECD Jobs Study (OECD 1994), which investigated the high and persisting unemployment in advanced countries and downplayed the role of technological change. The report emphasized the positive role of new technologies associated to structural change and showed employment decline in low-technology sectors and also in some R\&D intensive industries.

8. Meyer Kramer (1992) has used a model of the whole German economy to assess the impact of ICTs, proxied by direct and indirect $R \& D$ in 51 sectors. The findings suggest a generally negative employment impact, with some positive effects in higher technology industries.

9. An early use of these data for Italian manufacturing industry is in Vivarelli, Evangelista, and Pianta (1996), who found a generally negative employment impact of technological change and the expected contrasting consequences of product and process innovations. Pianta (2000, 2001) investigated five European countries (Denmark, Germany, Italy, the Netherlands, and Norway) in 1989-93 across twenty-one manufacturing industries, finding a positive employment effect of changes in demand and product innovations, and an overall negative impact of innovation intensity.

10. They argue that "The evidence supports the conclusion that an increase in the pace of innovation (all else equal) will raise both the natural rate of unemployment and the average length of time during which an unemployed worker is 'between jobs'” (p.10).

11. Their assumptions on productivity growth were based on the improvements in the engineering performance of robots. The long time-lags in their adoption and their poor initial performance have meant that their actual economic effect on productivity has been much lower.

12. Petit (1995) suggests that techniques and human labor had a complementary relationship in pre-industrial times, following strong social norms. Industrialization was characterized by the substitution of machines for labor on the basis of profit seeking; and the post-war rapid growth associated with technologies designed to overcome labor shortages and increase productivity, while the current emergence of a new technological system based on ICTs is marked by uncertainties.

13. Computer-related investment per employee rose from 150 \$US in 1982 to about 1000 \$US in 1992 for both manufacturing and services (Howell 1996: 292). The share of low-skilled blue collar US workers in manufacturing declined from 45.1 per cent in 1978 to 39.7 per cent in 1982 and has since then remained stable, ending in 1990 with a 41 per cent share. In the late 1980s, when ICTs became important, the most serious reduction in the employment shares concerned the high-skilled blue collars (which since 1978, had a stable share around 21.7 per cent, a share which declined after 1985 to 19.7 per cent in 1990) and the low-skilled white collars (a share which stayed stable at around 12 per cent until 1985 and then declined to 10.6 per cent in 1990). At the opposite end, the share of high-skilled white collars increased in the 1978-83 period (from 19.5 to 24.1 per cent), then was stable until a rise in 1989-1990 to 25.8 per cent (Howell 1996: 299, tables 1 and 2).

14. This may amount to a shift in "wage norms": "in the face of mounting competition, employers reduced unit labour costs and increased flexibility in the production process by following the 'low road'-lower wages, little training, and fewer permanent employees" (Howell 1996: 301). Combined with a large use of part-time and temporary workers, anti-union practices, relocation to low-wage sites and inflows of low-wage foreign workers, these developments have led to an increase in the supply of labor competing 
for low-skill jobs, leading to a major fall in their wages, accompanied by a 25 per cent reduction in the real minimum wage over the 1980 os (ibid. 292).

15. There is also a "national specificity" to most of the different approaches. The "skills" research is largely US-focused, while most industry-level studies focus on Europe. There is little English-language empirical work on the employment-innovation relationship in Japan or other Asian high-growth economies.

\section{REFERENCES}

*Acemoglu, D. (2002), “Technical Change, Inequality and the Labor Market," Journal of Economic Literature, 40(1): 7-72.

*Addison, J., and Teixeira, P. (2001), “Technology, Employment and Wages,” Labour 15(2): 191-219.

Adler, P. (ed.) (1992), Technology and the Future of Work, New York: Oxford University Press.

Antonelli, C. (2001), The Microeconomics of Technological Systems, Oxford: Oxford University Press.

Antonucci, T., and Pianta M. (2002), “The Employment Effects of Product and Process Innovations in Europe," International Review of Applied Economics 16(3): 295-308.

Appelbaum, E., and BAtT, R. (1994), The New American Workplace, Ithaca: ILR Press.

Autor, D., Katz, L., and Krueger, A. (1998), "Computing Inequality: Have Computers Changed the Labor Market?” Quarterly Journal of Economics 113: 1169-1214.

Bartel, A. P., and Lichtenberg, F. R. (1991), "The Age of Technology and its Impact on Employee Wages," Economics of Innovation and New Technology 1: 215-31.

— and Sicherman, N. (1999), "Technological Change and Wages: An Interindustry Analysis," Journal of Political Economy 107: 285-325.

Baumol W., and Wolff, E. (1998), Side Effects of Progress: How Technological Change Increases the Duration of Unemployment, Jerome Levy Economics Institute of Bard College, Public Policy Brief 41.

*Berman E., Bound, J., and Griliches, Z. (1994), "Changes in the Demand for Skilled Labor Within US Manufacturing Industries: Evidence from the Annual Survey of Manufactures," Quarterly Journal of Economics 109: 367-98.

—_ and Machin, S. (1998), "Implications of Skill Biased Technological Change: International Evidence," Quarterly Journal of Economics 113: 1245-79.

Black, S., and Lynch, L. (2000), "What's Driving the New Economy: The Benefits of Workplace Innovation,” NBER working paper 7479.

Boyer, R. (1988a), “Technical Change and the Theory of Régulation,” in Dosi et al. 1988: 67-94.

— (1988b), "Formalizing Growth Regimes," in Dosi et al. 1988: 608-35.

Braverman, H. (1974), Labour and Monopoly Capital, New York: Monthly Review Press.

\footnotetext{
* Asterisked items are suggestions for further reading.
} 
Bresnahan, T. F., Brynjolfsson, E., and Hitt, L. M. (2002), "Information Technology, Workplace Organization and the Demand for Skilled Labor: Firm-Level Evidence," Quarterly Journal of Economics 117: 339-376

Brouwer, E., Kleinknecht, A., and Reijnen, J. O. N. (1993), "Employment Growth and Innovation at the Firm Level: An Empirical Study," Journal of Evolutionary Economics 3: $153-9$.

Brynjolfsson, E., and Hitt, L. M. (2000), "Beyond Computation: Information Technology, Organisational Transformation and Business Performance," Journal of Economic Perspectives, 14: 23-48.

Caroli, E. (2001), "New Technologies, Organizational Change and the Skill Bias: What do we Know?" in Petit and Soete 2001: 259-92.

— and Van Reenen, J. (2001), "Skill Biased Organizational Change? Evidence From a Panel of British and French Establishments," Quarterly Journal of Economics 116(4): 1149-92.

Casavola, P., Gavosto, A., and Sestito, P. (1996), “Technical Progress and Wage Dispersion in Italy: Evidence from Firms' Data," Annales d'Economie et de Statistique (Jan.-June): 387-412.

Chennells, L., and Van Reenen, J. (1999), "Has Technology Hurt Less Skilled Workers? An Econometric Survey of the Effects of Technical Change on the Structure of Pay and Jobs," London: Institute for Fiscal Studies working paper 27.

Cyert R. M., and Mowery, D. C. (eds) (1988), "The Impact of Technological Change on Employment and Economic Growth," Cambridge, Mass.: Ballinger.

Doms, M., Dunne, T., and Trotske, K. (1997), “Workers, Wages, and Technology,” Quarterly Journal of Economics 112: 253-89.

Dosi, G., Freeman, C., Nelson, R., Silverberg G., and Soete L. (eds), (1988), Technical Change and Economic Theory, London: Pinter.

Edquist, C., Hommen, L., and McKelvey, M. (2001), Innovation and Employment: Product versus Process Innovation, Cheltenham: Elgar.

Entorf H., Gollac, M., and Kramarz, F. (1999), "New Technologies, Wages and Worker Selection," Journal of Labor Economics 17(3): 464-91.

European Commission-Eurostat (2001), Statistics on innovation in Europe. Data 1996-1997, Luxembourg: European Commission.

European Foundation for the Improvement of Living and Working Conditions (2001), Third European Survey on Working Conditions 200o. Dublin: European Foundation for the Improvement of Living and Working Conditions.

Evangelista, R., and Savona M. (2002), "The Impact of Innovation on Employment and Skill in Services. Evidence from Italy," International Review of Applied Economics 3: 2002.

- (2003), "Innovation, Employment and Skills in Services. Firm and Sectoral Evidence," Structural Change and Economic Dynamics (forthcoming).

Fagerberg, J., Guerrieri, P., and Verspagen, B. (eds.) (1999), The Economic Challenge for Europe: Adapting to Innovation Based Growth, Northampton: Elgar

*Freeman, C., and Louçã, F. (2001), As Time Goes by. From the Industrial Revolution to the Information Revolution, Oxford: Oxford University Press

_ and Soete, L. (1994), Work for All or Mass Unemployment? London: Pinter (eds.) (1987), Technical Change and Full Employment, Oxford: Basil Blackwell. Clark, J., and Soete, L. (1982), Unemployment and Technical Innovation, London: Pinter. 
FreY, L. (1997), "Il lavoro nei servizi verso il secolo XXI," Quaderni di Economia del Lavoro 57, Milan: Angeli.

Greenan, N. (2003), "Organisational Change, Technology, Employment and Skills: An Empirical Study of French Manufacturing," Cambridge Journal of Economics 27: 287-316.

— and Guellec, D. (2000), "Technological Innovation and Employment Reallocation," Labour 14(4): 547-90.

*Greenan, N., L'Horty, Y., and Mairesse J. (eds.) (2002), Productivity, Inequality and the Digital Economy, Cambridge: Mass., MIT Press.

Hansen, A. H. (1964), Business Cycles and National Income, London: Allen and Unwin (expanded edn.).

Heertje, A. (1973), Economics and Technical Change," London: Weidenfeld and Nicolson.

Howell, D. (1996), "Information Technology, Skill Mismatch and the Wage Collapse: A Perspective on the US Experience," in OECD 1996: 291-306.

— and WolfF, E. (1992), "Technical Change and the Demand for Skills by US Industries," Cambridge Journal of Economics 16: 128-46.

IPTS-ESto (Institute for Prospective Technology Studies, European Science and Technology Observatory) (2001), Impact of Technological and Structural Change on Employment. Prospective Analysis 2020, Synthesis Report and Analytical Report, Seville: European Commission Joint Research Centre.

Kalmbach P., and Kurz, H. D. (1990), "Microelectronics and Employment: A Dynamic Input-Output Study of the West German Economy," Structural Change and Economic Dynamics 1: 317-86.

Karaomerlioglu, A., and Ansal, T. (2000), "Compensation Mechanisms in Developing Countries," in Vivarelli and Pianta 2000: 165-81.

Katsoulacos, Y. S. (1986), The Employment Effect of Technical Change, Brighton: Wheatsheaf.

- Krueger, A. (1993), "How Computers have Changed the Wage Structure: Evidence from Micro Data 1984-1989," Quarterly Journal of Economics 108: 33-60.

Layard, R., and Nickell, S. (1985), "The Causes of British Unemployment," National Institute Economic Review 111: 62-85.

Leontief, W., and Duchin, F. (1986), The Future Impact of Automation on Workers, Oxford: Oxford University Press.

Lundvall, B. A. (1987), “Technological Unemployment in a Small Open Economy," In R. Lund, P. Pedersen, and J. Schmidt-Sorensen (eds), Studies in Unemployment, Copenhagen: New Social Science Monographs, Institute of Organisation and Industrial Sociology, 21-48.

Machin, S. (1996), "Changes in the Relative Demand for Skills," in A. Booth, and D. Snower (eds), Acquiring skills, Cambridge: Cambridge University Press, 129-46.

— and Van Reenen, J. (1998), "Technology and Changes in Skill Structure: Evidence from Seven OECD Countries," Quarterly Journal of Economics 113: 1215-44.

— and Wadhwani, S. (1991), "The Effects of Unions on Organisational Change and Employment: Evidence from WIRS,” Economic Journal 101: 324-30.

Meghir, C., Ryan, A., and Van Reenen, J. (1996), "Job Creation, Technological Innovation and Adjustment Costs: Evidence from a Panel of British Firms," Annales d'economie et statistique 41-2: 256-73.

Meyer-Kramer F. (1992), “The Effects of New Technologies on Employment,” Economics of Innovation and New Technology 2: 131-49. 
Nelson, R., and Phelps, E. (1966), "Investment in Humans, Technological Diffusion and Economic Growth," AEA Papers and Proceedings 56: 69-75.

- and Winter, S. (1982), An Evolutionary Theory of Economic Change, Cambridge, Mass.: Belknap Press.

Noble, D. (1984), Forces of Production: A Social History of Industrial Automation, New York: Knopf.

OECD (1994), The OECD Job Study. Evidence and explanations. Part I, Labour Market Trends and Underlying Forces of Change, Paris: OECD.

- (1996), Employment and Growth in the Knowledge-Based Economy, Paris: OECD.

Padalino, S., and Vivarelli, M. (1997), "The Employment Intensity of Economic Growth in the G-7 Countries," International Labour Review 136: 191-213.

Pasinetti, L. (1981), Structural Change and Economic Growth, Cambridge: Cambridge University Press.

Perez, C. (1983), "Structural Change and the Assimilation of New Technologies in the Economic and Social Systems, Futures 15(5): 357-75.

— Petit, P. (1995), "Employment and Technological Change," in P. Stoneman (ed), Handbook of the Economics of Innovation and Technological Change, Amsterdam: North Holland, 366-408.

- and Sozte, L. (eds) (2001a), Technology and the Future of European Employment, Cheltenham: Elgar.

_ (2001b), "Technical Change and Employment Growth in Services: Analytical and Policy Challenges," in Petit and Soete 2001a: 166-203.

Pianta, M. (2000), "The Employment Impact of Product and Process Innovation," in Vivarelli and Pianta 2000: 77-95.

- (2001), "Innovation, Demand and Employment," in Petit and Soete 2001a: 142-65.

— Evangelista, R., and Perani, G. (1996), "The Dynamics of Innovation and Employment: An International Comparison," Science, Technology Industry Review 18: 67-93.

PINI P. (1995), "Economic Growth, Technological Change and Employment: Empirical Evidence for a Cumulative Growth Model with External Causation for Nine OECD Countries, 1960-1990," Structural Change and Economic Dynamics 6: 185-213.

_ (1996), "An Integrated Cumulative Growth Model: Empirical Evidence for Nine OECD countries, 1960-1990," Labour 10: 93-150.

Piva, M., and Vivarelli, M. (2002), "The Skill Bias: Comparative Evidence and an Econometric Test," International Review of Applied Economics 16(3): 347-58.

Ricardo, D. (1951), Principles of Political Economy and Taxation, in P. Sraffa, (ed.), The Works and Correspondence of David Ricardo, vol. 1, Cambridge: Cambridge University Press (3rd edn. 1821).

Sanders, M., and ter Weel, B. (2000), "Skill biased technical change: theoretical concepts, empirical problems and a survey of the evidence," Druid working paper, Copenhagen Business School and Aalborg University.

Schumpeter, J. A. (1934), Theory of Economic Development, Cambridge, Mass.: Harvard University Press (1st edn. 1911).

Shaiken, H. (1984), "Work Transformed: Automation and Labor in the Computer Age," New York: Holt, Rinehart and Winston.

Simonetti, R., Taylor, K., and Vivarelli, M. (2000), "Modelling the Employment Impact of Innovation: Do Compensation Mechanisms Work?” in Vivarelli and Pianta 2000. 
— and TANCIONI, M (2002), "A Macroeconometric Model for the Analysis of the Impact of Technological Change and Trade on Employment," Journal of Interdisciplinary Economics 13: 185-221.

Smolny, W. (1998), "Innovation, Prices and Employment: A Theoretical Model and an Application for West German Manufacturing Firms," Journal of Industrial Economics 46: $359-81$.

Spiezia, V., and Vivarelli, M. (2002), "Innovation and Employment: A Critical Survey," in Greenan, L'Horty, and Mairesse 2002: 101-31.

Sylos Labini, P. (1969), Oligopoly and Technical Progress, Cambridge, Mass.: Harvard University Press (1st edn. 1956).

Van Reenen, J. (1996), "The Creation and Capture of Economic Rents: Wages and Innovation in a Panel of UK Companies," Quarterly Journal of Economics 111(1): 195-226.

_ (1997), "Employment and Technological Innovation: Evidence from U.K. Manufacturing Firms," Journal of Labor Economics 15: 255-84.

Vivarelli, M., Evangelista, R., and Pianta, M. (1996), "Innovation and Employment in the Italian Manufacturing Industry," Research Policy 25: 1013-26.

- Vivarelli, M. (1995), The Economics of Technology and Employment: Theory and Empirical Evidence, Aldershot: Elgar.

and Pianta, M. (eds.) (200o), The Employment Impact of Innovation: Evidence and Policy, London: Routledge.

Whitley, J. D., and Wilson, R. A. (1982), "Quantifying the Employment Effects of MicroElectronics," Futures 14(6): 486-95.

WolfF, E. (1996), “Technology and the Demand for Skills," Science Technology Industry 18: 95-124. 